\title{
ЗАСТОСУВАННЯ ЗЕМЕЛЬНОГО ЗАКОНОДАВСТВА ПРИ ЗДІЙСНЕННІ МІСТОБУДІВНОї ДІЯЛЬНОСТІ
}

\author{
БЕРЕЖНИЦЬКА Галина Іванівна - кандидат економічних наук, доцент \\ кафедри права факультету управління, економіки та права Львівського \\ національного аграрного університету \\ ORCID ID: https://orcid.org/0000-0003-4960-9485 \\ УДК 349.44 \\ DOI 10.32782/NP.2021.4.24
}

\begin{abstract}
В статье проведён анализ особенностей применения земельного законодательства при осуществлении градостроительной деятельности в Украине. Указано, что необходимость обновления градостроительной инфраструктурь, осовременивание внешнего вида города и функиионирование надлежащей сочиальной сберь указвьвает на необходимость дополнительного анализа норм градостроительного права.

Обращено внимание, что в романо-германской правовой семъе можно говорить о разграничении исследуемого отраслевого законодательства, однако в англо-саксонской системе права такая разница признается «искусственной», а также мотивирована обшность конечного результата.

Указано, что система национального права и законодательства отграничивает эти отрасли, что, в свою очередь, провочиpует коллизионность. В Украине действует комплексньй правовой акт в сфере земельныхх отношений - Земельный кодекс Украинъ, принятьлй двадцать лет назад. Однако, несмотря на столь длительную историю существования, такой кодифицированнвии акт не получил полноценной ниши в земельном законодательстве. Указанное обусловлено двумя обстоятельствами: значительным количеством норм бланкетного характера u регулирование дополнительно еще рядом специальных актов.

Указано на проблемъ понятийно-категориального понимания градостроитель-
\end{abstract}

ного права, поскольку его толкуют как институт экологического права, институт земельного права, подотрасль земельного права и комплексную отрасль права. Въгделенъ предмет и метод правового регулирования градостроительного права, ито дало возможность утверждать, ито его место имеет отраслевой, а не другой характер.

Анализ норм Закона Украинъ «О регулировании градостроительной деятельности» дал возможность выделить основнъе аспекть такого взаимодействия: обусловленность градостроительных норм челевыл назначением земли; земля для градостроительных нужд может бътьь легально передана в собственность исключительно при наличии градостроительной документации на местном уровне; изменение иелевого назначения земельного участка допускается исключительно при соблюдении правил соотношения между новълм видом иелевого назначения земельного участка и видом функиионального назначения территории, определенного соответствующей градостроительной докуменmau̧uей.

Рассмотрен межотраслевой институт территориального планирования в контексте интеграции норм градостроительного, земельного и административного права.

Ключевые слова: земельное право, земельное законодательство, градостроительное право, институт права, отрасль права, территориальное планирование. 


\section{Земельне право}

\section{Постановка проблеми}

Свроінтеграційні прагнення України мають передбачати комплекс правових, організаційних та соціальних заходів, що реалізовуються як на державному так і на місцевому рівні. У праксіологічному аспекті людського існування саме навколишній соціум забезпечує нагальні потреби існування. Тому побудова та функціонування населених пунктів відповідно до міжнародних та сучасних європейських стандартів вказуватиме на належну реалізацію зобов'язань держави.

Потреба оновлення містобудівної інфраструктури, осучаснення зовнішнього вигляду міста та функціонування належної соціальної сфери вказує на потребу додаткового аналізу норм містобудівного права. Децентралізація владних відносин та економічні чинники сприяли активізації забудови в містах по всій території України. В Україні громадська та житлова забудова, особливо в історичному центрі міст, дуже перевантажена надмірністю та хаотична. Однак цим додаткові проблеми не вичерпуються. Органи місцевого самоврядування не виконують містобудівні стандарти. Аналіз стану виконання вимог, передбачених Законом України «Про благоустрій населених пунктів», свідчить, що лише $17 \%$ (4681 населений пункт) мають затверджені програми з благоустрою, у містах цей показник становить - 77,4\% (340 міст). У місті Києві програма з благоустрою відсутня. Тільки 29,8\% (8258 населених пунктів) мають затверджені плани заходів з благоустрою і лише 5,4\% (1508 населених пунктів) мають програми розвитку та збереження зелених зон населених пунктів. У містах цей показник становить 44,4\% (195 міст). У місті Києві така програма зовсім відсутня [1]. Отож комплекс проблем має вагомий характер та потребує наукового та практичного аналізу.

Проте важливо розуміти, що лише нормами містобудівного права вирішити проблему неможливо, вагомо акцентувати увагу на комплексності проблематики, міжгалузевий характер методологіювання виступає необхідним елементом правового регулювання. Необхідними є формування зав'язків усталеного земельного права та законодавства 3 новоствореним містобудівним. Останне взаємодіє господарським, адміністративним, цивільним, житловим, природоохоронним пра- вом, однак найбільше точок дотику має саме із земельним правом. Взаємодетермінована дія різних комплексів законодавства вимагає узгодженості понятійно-категоріального апарату, засобів та методів функціонування та трансформація категорій у єдиноцентриську систему правозастосування. Неузгодженість норм різногалузевого спрямування тягне за собою колізійність правореалізаційної сфери та невизначеність правовідносин, сприяє порушенню законодавства та різнотлумачній практиці. Тому потребує комплексного аналізу сфера поєднання норм земельного та містобудівного права на сучасному етапі розвитку державності та суспільної реальності.

\section{Стан дослідження}

Деякі питання проблем будівництва, генерального плану населеного пункту, регулювання земельних ресурсів, забезпечення містобудівної діяльності розглядалися, зокрема, у доробках Д.С. Добряка, М.М. Дьоміна, В.М. Єрмоленка, О.С. Петраковської, А.Я. Новаківського, А.М. Третяка, О.І. Сингаӥвської, В.Д. Шипулін, А.А. Аященко та інших. Однак у сучасній національній доктрині відсутні доробки, які 6 розглядали інтегративний підхід у земельному та містобудівному праві. Як вказує у дисертації $\lambda$. Сенюта, «спеціальні комплексні дослідження системи вітчизняного земельного права не відводять жодного місця нормам містобудівного права у структурі земельного права, не розглядаючи їх навіть щодо земель житлової та громадської забудови» [2].

Метою статті є аналіз особливостей застосування земельного законодавства при здійсненні містобудівної діяльності в Україні.

\section{Виклад основних положень}

Слід звернути увагу, що в романо-германській правовій родині можна вести мову про розмежування досліджуваного галузевого законодавства, проте в англосаксонській системі права така різниця визнається «штучною» i, за твердженням Дж. Вільяса, усе право містобудівного, природоохоронного і земельного характеру є єдиним цілим [3].

Про спільну правову природу цих двох галузей вказує й Д. Адамс. Він виводить 
спільність зі спільного кінцевого результату, вказуючи, що «землевласники, забудовники, інвестори, політики та просто представники громадськості, які створюють зміни в містах, взаємодіють один з одним і реагують на тиск розвитку. Незалежно від того, чи відбуваються такі зміни повільно і майже непомітно, чи відбуваються швидко і є дуже руйнівними, виробничий процес створює готовий продукт: створене середовище» [4]. А також додамо, що їх об’єднують спільні глобальні плани, i, як вказують представники португальської школи права, досягнення «передової практики відновлення вільних земель для сталого розвитку міст» [5].

Система національного права та законодавства відмежовує ці галузі, що, у свою чергу, провокує колізійність, тому дослідимо основні поняття, а згодом визначимося 3 особливостями їх взаємодії.

Земля, відповідно до норм чинного законодавства, є основним національним багатством, що перебуває під особливою охороною держави, яка полягає у забезпеченні раціонального використання земельних ресурсів, збереженні й відтворенні родючості грунтів, захисті їх від псування та забруднення, реалізації громадянами, юридичними особами та державою їхніх прав власності та землекористування відповідно до закону.

В Україні діє комплексний правовий акт у сфері земельних відносин - Земельний кодекс України, що прийнятий двадцять років тому. Проте, не зважаючи на таку тривалу історію існування, такий кодифікований акт не отримав повноцінної ніші в земельному законодавстві. Вказане зумовлено, на нашу думку, двома обставинами. По-перше, значна кількість його норм має бланкетний характер, що ускладнює застосування положень Кодексу і дає підстави говорити про процеси декодифікації земельного законодавства [6]. По-друге, земельні відносини мають широкий характер і регулюються додатково ще цілою низкою спеціальних актів, зокрема відповідно до ст. 3 Земельного кодексу «земельні відносини, що виникають при використанні надр, лісів, вод, а також рослинного і тваринного світу, атмосферного повітря, регулюються цим Кодексом, нормативно-правовими актами про надра, ліси, води, рослинний і тваринний світ, атмосферне повітря, якщо вони не суперечать цьому Кодексу. Земельні відносини, що виникають при наданні та використанні земельних ділянок для розміщення об'єктів енергетики, встановлення та дотримання правового режиму земель спеціальних зон об'єктів енергетики, у тому числі на підставі договорів про встановлення земельних сервітутів на таких земельних ділянках, регулюються цим Кодексом, Законом України «Про землі енергетики та правовий режим спеціальних зон енергетичних об'єктів»». Вказане дає нам можливість зрозуміти про проблеми колізійного характеру навіть у межах лише земельного законодавства, оскільки значна кількість актів різної юридичної сили спричиняє неузгодженості та провокує різнотлумачення.

Щодо понятійно-категоріального розуміння містобудівного права, то справа ще складніша. Професор В Ермоленко вказує, що «наразі в наукових публікаціях містобудівне право розглядається як: 1) інститут екологічного права (правового регулювання забудови земель у системі екологічного права як комплексної галузі (Болтанова); 2) інститут земельного права (правового режиму земель населених пунктів (Крассов); 3) підгалузь земельного права (Ждан-Пушкина); 4) комплексна галузь права (Ізарова); 5) самостійна галузь права (Риженков; Анисімов, Юшкова). Таким чином, не з'ясованими залишаються місце містобудівного права у системі національного права, а також його галузеве «забарвлення» $[7$, с.86].

Для чіткої відповіді на те, чи є містобудівне право окремою галуззю, звернемося до теоретико-правових аспектів. Для розмежування класично прийнято брати предмет та метод правового регулювання. До першого можна віднести суспільні відносини, що діють у сфері просторового і територіального планування урбанізованих центрів, здійснюваного державними органами та органами місцевого самоврядування з метою планування і забудова територій та забезпечення раціонального розселення і визначення напрямів сталого розвитку територій. Вказані суспільні відносини, які виникають у сфері територіального планування, містобудівного зонування, планування території, архітектурно-буді- 


\section{Земельне право}

вельного проєктування, будівництва об’єктів капітального будівництва, а також капітального ремонту, при проведенні якого зачіпають конструктивні й інші характеристики надійності та безпеки таких об’єктів, пов’язані 3 правовим статусом суб'єктів відносин у містобудівній сфері, складають структуру містобудівного права. Метод правового регулювання передбачає як імперативні приписи, так i можливість використання диспозитивного регулювання. Вказане залежить від виду та особливостей суспільних відносин.

Вказане доводить можливість віднесення містобудівного права до окремої галузі права, оскільки займає окрему «нішу» в комплексі правових відносин, норм, методів, засобів та гарантій механізму правового регулювання.

Звернемося до законодавства. Вище цитований Земельний кодекс жодним чином не містить згадок про містобудівні норми, що до речі, є досить дивним у контексті використання цього унікального природного блага в соціальній інфраструктурі.

Первинний у часовому вимірі акт містобудівної сфери «Про основи містобудування» [8] від 16 листопада 1992 року також не містить згадок про земельне законодавство. Ст.6 цього Закону містить пояснення, що «законодавство України про містобудування складається з Конституції України, цього Закону, законів України «Про регулювання містобудівної діяльності», «Про архітектурну діяльність» та інших нормативно-правових актів, що видаються на їх виконання». Відсутня вказівка на правила використання земель у містобудуванні та співвідношення норм із земельним законодавством.

Інший комплексний спеціальний законодавчий акт у сфері містобудування «Про регулювання містобудівної діяльності» від 17 лютого 2011 року має прогресивніший характер. Будемо констатувати, що нормотворцю знадобилося десяток років, щоб акцентувати увагу на проблемі розмежування та узгодження земельного та містобудівного законодавства. Ч. 1 ст. 3 Закону України «Про регулювання містобудівної діяльності» унормовує питання взаємодії, визнаючи деякі джерела земельного права (зокрема, йде мова про Земельний кодекс України і Законом України «Про землеу- стрій») такими, що регулюють містобудівні відносини [9].

Ст. 24 «Про регулювання містобудівної діяльності» визначає особливості регулювання земельних відносин при здійсненні містобудівної діяльності. Аналіз цієї статті дає нам можливість виокремити основні аспекти такої взаємодії:

- обумовленість містобудівних норм цільовим призначенням землі (п.2 ч.2 ст. 24 «Забудова земельної ділянки здійснюється в межах іiі цільового призначення, встановленого відповідно до законодавства».

- земля для містобудівних потреб може бути легально передана у власність лише за наявності містобудівної документації на місцевому рівні;

- зміна цільового призначення земельної ділянки допускається лише за умови дотримання правил співвідношення між новим видом цільового призначення земельної ділянки та видом функціонального призначення території, визначеного відповідною містобудівною документацією.

У системі права України є інститути, які містять у собі контекст збігу декількох напрямків галузевого законодавства, і тоді передбачається потреба не в розрізненні, а навпаки в інтегруванні норм окремих галузей права. У містобудівному праві таким міжгалузевим інститутом є територіальне планування.

Першочергово він належить містобудівному праву. Як вказує В. Глазирин, «повноцінне науково прикладне забезпечення містобудування та територіального планування розвитку агломерацій на маркетингових засадах передбачає розробку та реалізацію конкретних генеральних планів, що ув'язані 3 проєктами територіального розвитку відповідних агломерацій на основі проєктів детального планування та здійснення заходів 3 ландшафтної, архітектурно-просторової, естетичної та інфраструктурної організації території. Кінцевий результат полягає у створенні комфортних умов для праці, побуту i відпочинку, спектр яких у змозі задовольнити економічні, соціальні та культурно-побутові потреби жителів та відвідувачів агломерацій» [10].

Долучається до регулювання інституту планування ще й земельне, тому що питання 
зонування земель, визначення їх цільового призначення, склад земель населених пунктів, повноваженнями органів управління у сфері земельних відносин як прийняття рішення про резервування земельної ділянки, іiі вилучення для державних чи муніципальних потреб, наданні зацікавленим громадянам чи юридичним особам земельних ділянок із земель державної або муніципальної власності, - усе це регулює земельне законодавство. В цьому контексті О. Ущаповська вказує, що «сучасною юридичною доктриною планування в земельному праві розглядається як один 3 принципів правового регулювання земельних відносин, як функція державного регулювання земельних відносин, як нормативно закріплений зовнішній вираз соціальної діяльності суб'єктів публічного і приватного права, спрямованої на розроблення і узаконення передбаченої у земельному, містобудівному, екологічному та іншому законодавстві планувальної документації» [11, с. 14-15].

Академік В. Ермоленко доводить, що формування правового механізму планування територій у містобудуванні відбувається повністю в руслі принципу утворення комплексних галузей права, коли містобудівне законодавство, взявши за основу вищенаведені загальні положення земельного законодавства, деталізує їх щодо власних потреб. Так, надане у ч. 1 ст. 2 Закону України «Про регулювання містобудівної діяльності» визначення «планування територій, розгалужується на 14 напрямів містобудівної діяльності, одним з яких є визначення і раціональне взаємне розташування зон житлової та громадської забудови, виробничих, рекреаційних, природоохоронних, оздоровчих, історико-культурних та інших зон і об'єктів. Проте у зазначеній ч. 1 ст. 2 Закону України «Про регулювання містобудівної діяльності» одним із пунктів поряд із зонуванням (п. 5) передбачається обгрунтування розподілу земель за цільовим призначенням (п. 3), що виключає у містобудуванні протиставлення зонування та цільового використання земель, втім, як і у земельному законодавстві (ст. 20 ЗК України)» [12, с.23].

До того ж, вказаний інститут безпосередньо пов'язаний з управлінською діяльністю органів публічної влади, що дає можливість вести мову про вплив на нього норм адміні- стративного права, а також актуальними в цьому аспекті є питання децентралізації влади, тому конституційні норми також можуть мати місце при реалізації діяльності з приводу територіального планування. Подальші заходи із децентралізації у сфері використання та охорони земель запроваджуються у липні 2021 р. після набуття чинності Законом України «Про внесення змін до деяких законодавчих актів України щодо планування використання земель» від 17 червня 2020 р., яким передбачено, зокрема, утворення громадами власних органів містобудування та архітектури, які зможуть встановлювати містобудівні умови та обмеження на всій території громади. Буде забезпечена можливість коригування функціональних зон, встановлених старими генеральними планами населених пунктів, за допомогою детальних планів території, за винятком території парків, скверів, лісів та прибережних захисних смуг. Зміни, внесені згаданим вище Законом до земельного законодавства, спрямовані на забезпечення можливості громадам складати схеми просторового планування своєї теритоpiї, які є інструментом комплексного управління у сфері використання земель громади, встановлювати їх призначення, здійснювати зонування території та визначення напрями iї збалансованого розвитку [13, с.145].

Своє твердження щодо перехресного перетину низки галузей права в інститутах містобудівного права підтвердимо прикладом судової практики. Компанія «Лемберг Медікал Центр» подала позов до адміністративного суду і хоче визнати протиправним затвердження меж історичного ареалу Аьвова. Йдеться про оскарження рішення «Про затвердження меж історичного ареалу та зони регулювання забудови міста Аьвова», яке виконком затвердив у грудні 2005 року Рішення № 1311 [14]. Це - основний документ, який використовує Львівська міська рада, щоб регулювати забудову в історичній частині міста. Позивач посилається на порушення норм земельного (у контексті земель культурно-історичного призначення), містобудівного (територіальне планування) та адміністративного права (оскарження рішення органів публічної влади). Як ми бачимо, на практиці проблематика зазвичай має комплексний характер. 


\section{Висновок}

Вмотивовано подвійну природу норм земельного законодавства в містобудівному праві. 3 одного боку, ці дві галузі мають окремі сфери регулювання, проте аналіз норм Закону України «Про регулювання містобудівної діяльності» дав можливість виокремити основні аспекти такої взаємодії: обумовленість містобудівних норм цільовим призначенням землі; земля для містобудівних потреб може бути легально передана у власність лише за наявності містобудівної документації на місцевому рівні; зміна цільового призначення земельної ділянки допускається лише за умови дотримання правил співвідношення між новим видом цільового призначення земельної ділянки та видом функціонального призначення території, визначеного відповідною містобудівною документацією.

Розглянуто міжгалузевий інститут територіальне планування в контексті інтеграції норм містобудівного, земельного та адміністративного права та вказано на можливості їх компліментарності та взаємодоповненості.

\section{Лiтература}

1. Аналіз стану виконання вимог Закону України «Про благоустрій населених пунктів» за 2020 рік URL: https://www.minregion.gov. ua/napryamki-diyalnosti/zhkh/terretory/analizstanu-vykonannya-vymog-zakonu-ukrayinypro-blagoustrij-naselenyh-punktiv-za-20

2. Сенюта А.Б. Система земельного права України як галузі права: автореф. дис. ... канд. юрид. наук: 12.00.06; Ін-т держави i права ім. В.М. Корецького НАН України. Київ, 2019. 16 с.

3. Williams, J.. American Land Planning Law: Case and Materials, Volume 1 (1st ed.). Routledge. 2017. URL: https://doi. org/10.4324/9781315082615

4. Adams D. Urban Planning And The Development Process (1st ed.). Routledge. 2017. URL: https://doi.org/10.4324/9780203857007

5. Ribeiro A., Carvalho R., Madureira L. Establishing Urban Gardens on Vacant Land While Considering International Good Practices: A Legal Case Study from Portugal. In: Mauerhofer V., Rupo D., Tarquinio L. (eds) Sustainability and Law. 2020. Springer, Cham.
URL: https://doi.org/10.1007/978-3-030-42630935

6. Мірошниченко А. М. Колізії в правовому регулюванні земельних відносин в Україні: монографія. Київ: Алеута; КНТ; ЦУЛ, 2009. 270 с.

7. Ермоленко В. М. Містобудівне право в системі права України Право. Людина.Довкілия. 2019. Вип. 10, № 4. С. 85-94. С. 86

8. Про основи містобудування: закон України від 16.11.1992 № 2780-XII Відомості Верховної Ради України 1992, № 52, ст.683

9. Про регулювання містобудівної діяльності: закон України від 17.02.2011 № 3038-VI Відомості Верховноӥ Ради Украӥни. 2011, № 34, ст.343

10. Глазирин В. А., Шкрабик Й. В., Сахацький М. П. Містобудування та територіальне планування розвитку агломерацій: маркетинговий аспект Наукові вісті Далівсъкого університету. 2018. № 14. URL: http://nbuv. gov.ua/UJRN/Nvdu_2018_14_6

11. Ущаповська O.I. Планування в земельному праві України: автореф. дис. ... канд. юрид. наук: 12.00.06; Нац. юрид. ун-т імені Ярослава Мудрого. Харків, 2019. 20 с

12. Ермоленко В. М. Взаємозв'язки містобудівного і земельного права Право. Аюдина. Довкілля. 2020. Вип. 11, № 1. С. 19-26.

13. Коваленко Т. О. Розвиток земельного законодавства на сучасному етапі: до 20-річчя прийняття земельного кодексу України Держава і право. Юридичні і політичні науки. 2021. Вип. 89. С. 136-148. С. 145

14. Депутат облради намагається скасувати межі історичного ареалу Аьвова в суді URL: https://lviv.nashigroshi.org/2021/10/13/ kozlovskyj-v-sudi-namagayetsya-skasuvatymezhi-istorychnogo-arealu-lvova/

\section{APPLICATION OF LAND LEGISLATION IN THE IMPLEMENTATION OF URBAN PLANNING ACTIVITIES}

The article analyzes the features of the application of land legislation in the implementation of urban planning activities in Ukraine. It is indicated that the need to update the urban planning infrastructure, modernize the appearance of the city and the functioning of the proper social sphere indicates the need 


\section{АНОТАЦІЯ}

У статті проведений аналіз особливостей застосування земельного законодавства при здійсненні містобудівної діяльності в Украйні. Вказано, що потреба оновлення містобудівної інбраструктури, осучаснення зовнішнъого вигляду міста та фуукиіонування належної соціальної сбери вказує на потребу додаткового аналізу норм містобудівного права.

Звернуто увагу, що в романо-германсвкій правовіи родині можна вести мову про розмежування досліджуваного галузевого законодавства, проте в англосаксонській системі права така різниия визнається «итучною», а також мотивовано спільність кінцевого результату.

Вказано, що система національного права та законодавства відмежовує чі галузі, що, у свою чергу, провокує колізійність. В Украӥні діє комплексний правовий акт у сфері земельних відносин - Земельний кодекс України, що прийнятий двадиять років тому. Проте, не зважаючи на таку тривалу історію існування, такий кодибікований акт не отримав повноцінної ніші в земельному законодавстві. Вказане зумовлено двома обставинами: значною кількістю норм бланкетного характеру та регулювання додатково ще иілою низкою спеціальних актів.

Вказано на проблеми понятійно-категоріального розуміння містобудівного права, оскільки його тлумачать як інститут екологічного права, інститут земельного права, підгалузь земельного права комплексну галузь права. Виокремлено предмет та метод правового регулювання містобудівного права, що дало можливість стверджувати, що його місие має галузевий, а не інший характер.

Аналіз норм Закону Украӥни «Про регулювання містобудівної діяльності» дав можливість виокремити основні аспекти такої взаємодї: обумовленість містобудівних норм изільовим призначенням землі; земля для містобудівних потреб може бути легально передана у власність лище за наявності містобудівної документациї на місцевому рівні; зміна цільового призначення земельної ділянки допускається лише за умови дотримання правил співвідношення між новим видом иільового призначення земельної ділянки та видом функиіонального призначення територї, визначеного відповідною містобудівною документацією.

Розглянуто міжгалузевий інститут територіальне планування в контексті інтеграциї норм містобудівного, земельного та адміністративного права.

Ключові слова: земельне право, земельне законодавство, містобудівне право, інститут права, галузь права, територіальне планування. for additional analysis of the norms of urban planning law.

Attention is drawn to the fact that in the Romano-Germanic legal family we can talk about the differentiation of the studied sectoral legislation, however, in the Anglo-Saxon system of law, such a difference is recognized as "artificial", and the generality of the final result is also motivated.

It is indicated that the system of national law and legislation delimits these sectors, which in turn provokes conflict. Ukraine has a comprehensive legal act in the field of land relations - the Land Code of Ukraine, adopted twenty years ago. However, despite such a long history of existence, such a codified act did not receive a full-fledged niche in land legislation. This is due to two circumstances: a significant number of blanket rules and regulation in addition to a number of special acts.

The problems of the conceptual and categorical understanding of urban planning law are pointed out, since it is interpreted as an institution of environmental law, an institution of land law, a sub-branch of land law and a complex branch of law. The subject and method of legal regulation of urban planning law are highlighted, which made it possible to assert that its place is of a sectoral and not of another nature.

Analysis of the norms of the Law of Ukraine «On the regulation of urban planning activities» made it possible to highlight the main aspects of such interaction: conditionality of urban planning norms by the purpose of land; land for urban planning needs can be legally transferred into ownership only if there is urban planning documentation at the local level; a change in the designated purpose of a land plot is allowed only if the rules for the relationship between the new type of designated purpose of the land plot and the type of functional purpose of the territory determined by the relevant urban planning documentation are observed.

The inter-sectoral institute of territorial planning is considered in the context of the integration of the norms of urban planning, land and administrative law.

Key words: land law, land legislation, town planning law, institute of law, branch of law, territorial planning. 